\title{
Leadership Style and Turnover Intention: The Moderating Role of Supervisor Trust
}

\author{
Obaid Aldarmaki, Narimah Kasim
}

\begin{abstract}
Turnover Intention is a big issue for organizations because it costs huge capital investment in human resources. In United Arab Emirates (UAE), the turnover is higher than all other gulf countries and above the world average. Most of previous studies focused on the private sector and few examined the turnover in public sector. The purpose of this study is to examine the effect of leadership style and trust in supervisor on the turnover intention. Data was collected from 101 respondents from public sector in UAE. The data will be analyzed using Smart Partial Least Square (PLS). The findings showed that leadership styles as well as transformational leadership and transactional leadership have negative effects on turnover intention. In addition, trust in supervisor has direct negative effect on turnover intention. Decision makers are recommended to implement the transformational leadership and to establish a trusting relationship with employees.
\end{abstract}

Index Terms-Leadership, Public Sector, Turnover Intention, Transformational leadership, Trust

\section{INTRODUCTION}

Turnover intention (TI) of employees is one of the important topics that have attracted the attention of decision makers and researchers. This is because turnover intention has negative consequence on several outcomes such as employee and organizational effectiveness, competitive advantage, performance, productivity and service quality [1]-[3]. TI is defined as employee's intention to voluntarily leave a job [5]. Organizations are investing huge capital in preparing and training employees and this capital investment is lost when employees leave the job and therefore organizations need to invest again in developing and training employees[6]. For example, in United States (US) companies annually spend approximately US\$ 11 billion to start recruiting, selecting, hiring and training of employees [7]. The turnover intention in United Arab Emirates (UAE) is the highest among Arab gulf countries and above the world average. Organizations in UAE spend US\$ 2.7 billion annually to cover the direct and indirect cost of turnover among employees [8]. Official statistics from the Federal Authority for Government Human Resources (FAHR) in

2014 indicated that $5 \%$ of the workforce in public sectors has left their jobs. In 2012, the percentage of those who left their job was $3.6 \%$ indicating an increasing trend of job leavers among the nationals UAE.

\section{Revised Manuscript Received on June 22, 2019}

Obaid Aldarmaki, Department of Construction Management, Faculty of Technology Management and Business, Universiti Tun Hussein Onn Malaysia (UTHM), 86400 Parit Raja, Johor, Malaysia

Narimah Kasim, Department of Construction Management, Faculty of Technology Management and Business, Universiti Tun Hussein Onn Malaysia (UTHM), 86400 Parit Raja, Johor, Malaysia.
The report also indicated that from the $5 \%$, the voluntary Turnover was $50.4 \%$ in 2013 and it increased to $63.1 \%$ in 2014. For this reason, this study is focusing on the national public servants.

Previous studies attempted to understand the predictors that lead to TI among employees. Majority of previous studies investigated the organizational commitment, job satisfaction, and organizational support as the dominating predictors of TI [9]-[14]. Important predictor, yet neglected

in previous studies, is the leadership style. Previous studies highlighted that poor leadership is one of the main reasons for turnover intention [15], [16]. Most prevalent leadership styles are the autocratic and directorate while other styles such as transformational and transactional are not widely investigated in UAE [17]. Transformational and transactional leaderships can help in explaining the turnover intention [18]. In addition, trust in the context of management and business research is still in its infancy [19], [20]. Trust was investigated by few studies in the context of turnover intention [21] and the role of trust as a moderating variable could potentially help in explaining the variation in organizational outcome [22], [23].

Previous studies suggested to investigate the turnover intention among police personnel in UAE [21] due to the importance of these personnel in protecting the country [2]. Reports indicated that there are 17,291 police personnel are employed by the Abu Dhabi in 2014 (the capital city and the highest number of public servants employed by the state). This number has increased to 34,000 in 2017 and expected to reach 47,500 in 2021 [24]. Alhashmi[2]reported that the military jobs in UAE is one of the highest stressed job and majority of the turnover comes from this group. For this reason, this study aims to investigate the effect of leadership style and turnover intention as well as the moderating role of supervisor trust between leadership style and turnover intention.

\section{LITERATURE REVIEW}

\section{Turnover Intention}

Turnover is a global problem and it is costing organizations and countries a huge amount of fund. This trend of increasing obvious in UAE and other Gulf Countries Council (GCC). Employment laws in the host countries are making it relatively easy for employees to change jobs [25].Employees are the most important and valuable assets of any organization [26].

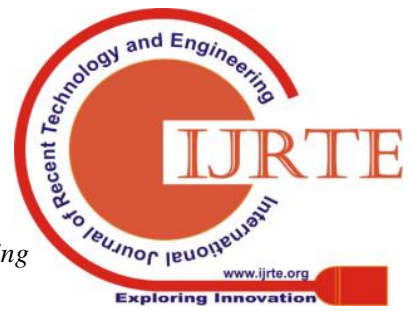


Organizations invest in employees and develop their skills and capabilities to create competitive advantage and improve their

Organizational performance (OP). Researchers pointed out those employees are the source of resource and capabilities and their knowledge has a major impact on the competitive advantage and the OP of organizations [6], [20], [22], [27]. Therefore, when some employees leave voluntarily their jobs, part of the resources and the capabilities of the organizations will go with them and this will impact the competitive advantage as well as the performance of these organizations [28].

Majority of researchers divided the TI into voluntary and involuntary turnover intention[29]-[31]. Voluntary turnover happens when the employee decides to leave his or her work in an organization, whereas involuntary turnover refers to organizations choosing to dismiss employees [30]. In this study, the focus is on the voluntary turnover.

Despite the scarcity of job opportunities, employees in UAE are intended to leave their job and seek employment with other employers. Reasons behind the turnover intention were linked to and trust as well as the leadership style of organizations [8], [25], [32]. Despite the high rate of turnover intention in UAE, the academic studies that investigated the issue are limited [21]. A study conducted by [33] investigated the turnover intention among Dubai organizations focused on the effect of procedural and distributive justice as well as job satisfaction and organizational commitment on turnover intention.

Another study was conducted by [34] on Islamic banks was limited to 70 respondents and conducted a correlational analysis using SPSS to find the effect of decision making, performance reward, organizational justice, and chances to innovate on turnover intention. The authors concluded that decision making, justice and chance to innovate has negative correlation with turnover intention. Similarly, the study of [35] was a correlational study and used SPSS to find the correlation between job satisfaction and organizational commitment as well as turnover intention among nurses in hospital in UAE. Harhara[30]conducted a conceptual study to identify the factors that affect turnover intention among oil and gas companies. The authors made a proposition that individual, organizational, and environmental factors affect the turnover intention. Behery [36]investigated the effect of relational psychological contract on turnover intention mediated by satisfaction and organizational commitment in UAE's private and public organizations.

Zeffane and Melhem[21]pointed out the lack of studies on turnover intention in UAE and the lack of including trust as a variable in the context of turnover intention. The authors investigated the effect job satisfaction organizational performance, trust, and demographic on turnover intention. A moderator based on sector was used. Finding indicated that public sector employees tend to be more trusting, satisfied. On the other hands, trust and satisfaction are the main drivers for turnover intention in private sector. In disagreement with the findings of [21], the study of [14] investigated the effect of job satisfaction and organizational commitment of local government employees in UAE and found that employees are highly satisfied with supervision and co-workers and slightly satisfied with work condition and job security and low satisfaction with pay. Employees are still working because they have to but not because they like to work.

The academic studies related to the turnover intention in public sector is limited and there is a need for a study to examine the predictors of turnover intention among national UAE. Existed studies were limited to correlational and conceptual studies as well as limited in term of sample size and the focus on studies on one gender. However, FAHR (2014) reported that national males are more likely to leave job compared with female. Consequently, there is a need for causal studies that investigate the turnover intention and deploy variables that reflect the issue among police personnel in the public sector of UAE.

\section{Leadership Style}

The theory of transformational leadership was developed by [37]. Transforming or changing the organization is the core principle of transformational leadership. According to [38] the transforming approach changes the lives of individual and organizations. It mainly focuses on redesigning the perception and values as well as changing the aspirations and expectations of employees. In contrast, the transactional approach of leadership focuses on mutual interest or based on give and take principle. However, the personality and traits as well as the ability of the leader to make changes based on example as well as energizing vision and challenging goals and objectives. The transformational leaders are considered ideal in giving example of working toward achieving the goals of individual, team, organization, and the community [38].

The work in transformational leadership was extended and developed by Bass in 1985 [39]. The work of [39] focused on creating and explaining the psychological mechanisms that underline the concept of transactional and transformational leadership. The term transformational leadership was used for the first time by [39]. In addition, the measurement of the transformational leadership was developed by[39] further, the mechanism through which the transformational leadership affects the performance and motivations of followers was explained by [39].

On the other hand, the concept of transactional leadership focuses on creating clear structure for what is the right of the followers and the rewards that they will received if they accomplish the required job is well defined. Followers in the transactional leadership are projected as individuals that are motivated by financial benefits and rewards and their behaviour is well predicted. Transactional leaders focus on the present and are very good at getting the organization to function smoothly and efficiently. However, although transactional leadership implies following certain rules and works very well in times of stability, in the changing world we find ourselves in today, where the success of companies often depends on continuous changes, there are more leadership styles effective [40].

A meta-analysis study conducted by [41] found that leadership style is dependent on gender.

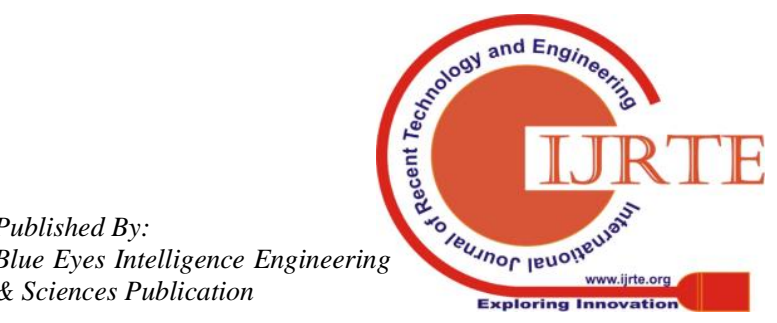


The authors compared between transactional, transformational and Laissez-Faire leadership and concluded that transformational is widely adopted by females while male deploys transaction leadership style.

[42] Pointed out that the use of transformational leadership by public sector was criticized by researchers. The authors pointed out that implementing transformational leadership in public sector is challenging due to the complex environments of this sector and the need to take into consideration the legal, regulatory, and policy demand. Nevertheless, researchers have deployed the transformational and transactional leadership to understand their effects on the turnover intention in public sector [43], [44] and on work attitude in private sector [13], [45], [46]. This study deployed the theory of transformational and transactional leadership to explain the effect of leadership styles on turnover intention.

\section{Trust in Supervisor}

In social relations, individuals attempt to maximize the ratio of profits to costs [47]. Trust is the fundamental principle of social exchange and the backbone of interpersonal and inter-organizational relationships [27][48]. [49] pointed out that trust is a key element of the social exchange theory and used the theory to explain the relationship between trust and uncertainty and their effect on the performance of alliance. [50] used the social exchange theory to explain the effect of trust in immediate supervisor and trust in organization with organizational justice in Saudi Arabia. The authors pointed out that social exchange theory explained perfectly the relationship between the variables. Trust in supervisor is expected to moderate the effect of leadership style on turnover intention among police personnel in UAE.

\section{CONCEPTUAL FRAMEWORK AND HYPOTHESES TESTING}

Based on leadership style and the theory of social exchange, this study proposes that the effect of leadership style on TI will be negative. The study also proposed that the effects of leadership style on TI will be moderated by trust in supervisor. Figure 1 presents the conceptual framework of this study.

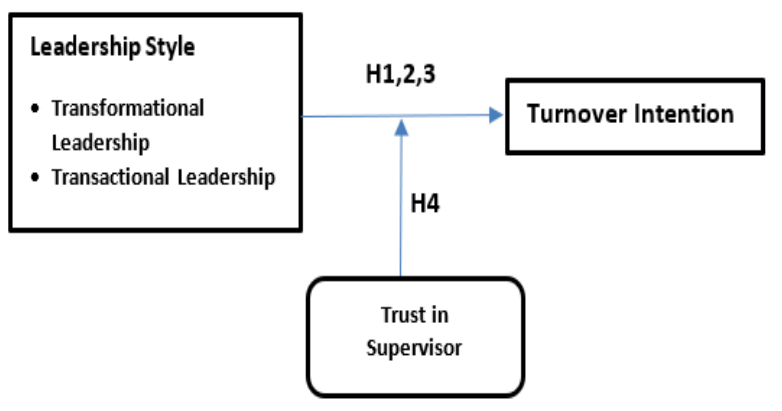

Fig. 1 Conceptual Framework

Based on the framework and the literature review, the following section discusses the hypotheses of this study.

\section{Leadership Style and Turnover Intention}

Leadership style in this study consists of transformational leadership and transactional leadership. The transformational leadership was defined as "a process in which leaders and followers raises one another to higher levels of morality and motivation"[37]. The transactional leadership was defined as "an exchange leadership style which motivates employees to produce the desired results"[39]. The two leaderships were investigated by few researchers in the turnover intention context.

[45] investigated the effect of transformational leadership on the turnover of employees in china and found that there is a negative effect between the variables. [13]in Turkey found that transactional leadership did not affect the quality of working life while transformational does. Leadership behavior could affect the turnover intention in oil and gas companies in UAE as proposed by [30].

[43] found that transformational leadership affect the turnover intention while transactional did not. [51]also found that transformational leadership affect the turnover intention. In contrast, [46] found that transformational leadership did not affect the turnover intention in Ghana. Leadership style (transformational and transactional) was proposed to affect the turnover intention in manufacturing companies in Malaysia. Based on the above discussion, this study expects that the effect of leadership style (transformational and transactional) is negative and significant on turnover intention of employees in public sector in UAE. Accordingly, the following is hypothesized:

$\mathrm{H} 1$ : Leadership style has a negative significant effect on turnover intention

H2: Transformational Leadership has a negative effect on turnover intention

H3: Transactional leadership has a negative effect on turnover intention.

\section{Moderating Role of trust in supervisor}

Trust is defined as "the positive expectations individuals have about the intent and behaviours of multiple organizational members based on organizational roles, relationships, experiences, and interdependencies"[52].Low trust in supervisor is one of the cause that lead to turnover intention. However, the research into trust and turnover intention received less attention as pointed out by [21] who found that trust is the main driver for turnover intention. Trust also found to cause the turnover intention among employees in Netherland [53].

[50] Tested the direct and mediating effect of trust in supervisor and trust in organization between organizational justice and performance. Few tested the moderating effect of trust in supervisor. For example, [54] tested the moderating effect of trust in supervisor (leader) and trust in organization between organizational support and turnover intention and between leader-member exchange and turnover. They found that both trust in leader and trust in organization moderated the effect between the variables. In this study, trust is expected to moderate the negative effect of leadership style on turnover intention. 
Thus, the following is hypothesized:

H4: Trust in supervisor moderates the effect of leadership style and organizational justice on turnover intention.

\section{METHODOLOGY}

This study is conducted in UAE and particularly on public sector employees. Among the public sector, police personnel are exposed to high level of stress due to work duties and their essential role in protecting the nation. Accordingly, the population of this study is the police personnel in Abu Dhabi. Statistic showed that a total of 34,000 are working as police personnel in Abu Dhabi [2]. These 34,000 police personnel are working in eight departments. A stratified sample was used to better represent the population. Based on [55], the sample size of this study is 380 respondents divided into eight groups based on the number of employees in each department.

A questionnaire was used to collect the data. The turnover intention (3 items) was adopted from [1]. Transformational leadership (15 items) and transactional leadership (7 items) were adopted from [56]. Trust in supervisor ( 8 items) was adopted from [57][54]. The questionnaire was validated by experts and a pilot study was conducted prior to field data collection. A total of 380 respondents were invited to answer the questionnaire. After giving adequate time and following a proper follow up, a total of 104 answered the questionnaire. These 104 responses are sufficient for using partial least square structural equation modelling (PLSSEM) [58].

The data was analyzed to check for missing value, outliers, normality, and multicollinearity. No missing values were identified. However, three responses were deleted on the basis of outliers. Data was normally distributed because skewness and kurtosis are less than absolute two and no multicollinearity issues among the variables.

\section{RESULT AND DISCUSSION}

\section{Profile of Respondents}

A total of 101 respondents have participated in this study. Descriptive analysis using SPSS was deployed to presents the profile of the respondents. The majority of the respondents $(89.1 \%)$ are males with age $(69.3 \%)$ between 26 and 39 and they are married (77.2\%). The respondents are holders of bachelor degree (35.6\%) and master degree $(32.7 \%)$ with experience as police personnel $(94.1 \%)$ of more than five years. The highest percentage (66.3\%) works as administrative.

\section{Measurement model}

Hair [59]suggested that the measurement model can be assessed by examining the factor loading (FL), Cronbach's Alpha (CA), composite reliability (CR), and average variance extracted (AVE). Two items from transformational leadership and one items from trust in supervisor were removed due to low factor loading. After removing the items, the factor loading for all items were greater than 0.70 as well as the CA and CR were greater than 0.70. AVE was found greater than 0.50 for all variables and its root square was greater than the cross loading of on other variables suggesting that the convergent validity and discriminant validity were achieved.

\section{Structural Model}

Hair [59] suggested that the structure model must be assessed using four criteria. The R-square was assessed and the variables of this study were able to explain 0.497 of turnover intention indicating that $49.7 \%$ of the variation in turnover intention can be explained by leadership style. The predictive relevance was also examined and the independent variables can predict the dependent variables because the $\mathrm{Q}^{2}$ were greater than zero. Further, the effect size for all the paths were acceptable and greater than 0.02. The path coefficient is presented in Table 1. The Table presents the results of direct effect hypotheses as well as the moderating hypotheses. Hypotheses' number $(\mathrm{H})$, path, path coefficient $(\beta)$, standard deviation (SD), T-values (T), P-values (P), and remark are given in the table.

Table. 1 Result of Hypotheses Testing

\begin{tabular}{|c|c|c|c|c|c|}
\hline H & Path & $\boldsymbol{\beta}$ & SD & T & P \\
\hline \multicolumn{7}{|c|}{ Direct Effect } \\
\hline $\begin{array}{c}\text { H } \\
1\end{array}$ & LS -> TI & -0.684 & 0.051 & $\begin{array}{c}13.42 \\
8\end{array}$ & 0.000 \\
\hline $\begin{array}{c}\text { H } \\
2\end{array}$ & TF -> TI & -0.579 & 0.074 & 7.794 & 0.000 \\
\hline $\begin{array}{c}\text { H } \\
3\end{array}$ & TS -> TI & -0.218 & 0.064 & 3.424 & 0.001 \\
\hline \multicolumn{7}{|c|}{ Moderating Effect of } \\
\hline \multirow{2}{*}{$\begin{array}{c}\text { H } \\
4\end{array}$} & $\begin{array}{c}\text { LS TIS -> } \\
\text { TI }\end{array}$ & -0.157 & 0.096 & 1.637 & 0.102 \\
\cline { 2 - 6 } & TIS -> TI & -0.276 & 0.043 & 6.418 & 0.007 \\
\hline
\end{tabular}

Note: TF: transformational leadership, TS: Transactional leadership, LS: leadership style, TI: Turnover intention, TIS: trust in supervisor.

The findings of the analysis indicated that the effect of leadership style (LS) on TI is negative and significant supporting the first hypothesis (H1) of this study. The effect of transformational leadership (TF) on TI is negative indicating that the second hypothesis $(\mathrm{H} 2)$ is accepted. For the third hypothesis, the effect of transactional leadership (TS) on TI is negative and significant supporting the third hypothesis of this study.

For the moderating effect of trust in supervisor, the finding indicated that there is no moderating effect. However, the findings showed that the effect of trust in supervisor is directly negative on turnover intention. Thus, fourth hypothesis is rejected.

\section{DISCUSSION}

The purpose of this study was to investigate the effect of leadership style on turnover intention among police personnel in UAE. 
The study also examined the moderating effect of trust in supervisor. The findings indicated that leadership style has significant negative effect on turnover intention. In addition, the transformational leadership has comparatively stronger negative effect than transactional leadership on turnover intention.

This finding indicates that the leadership style is essential to reduce the turnover intention among police personnel in UAE. In particular, the increase in the implementation and practicing of transformational leadership will lead to a decrease in the turnover intention. The transactional leadership is also effective in reducing the turnover intention among employees. These findings are in agreement with the findings of previous studies such as [13], [30], [43], and [45] which found that the transformational leadership as well as the transactional and leadership styles have significant negative effect on turnover intention among employees.

The findings of this study also found that trust in supervisor did not moderate the effect of leadership style on turnover intention. However, the study found that the trust in supervisor has direct negative significant effect on turnover intention. This indicates that trust is essential for reducing the turnover intention and it plays a vital role in improving the attitude of police personnel toward their jobs. This finding is consistent with the findings of [52],[21][53] and [50] who examined the direct effect of trust on organizational outcome and turnover intention and found that trust can reduce directly the turnover intention and improve other organizational outcome such as justice and performance. The findings of this study in term of the moderating effect is inconsistent with the findings of [54] who found that trust played a moderating role. However, this could be due to the difference in the scope of the studies as this study deals with police personnel which their job involve certain degree of risk and for them trust is fundamental for their work and their attitude toward their work.

\section{CONCLUSION}

This study examined the effect of leadership and trust on turnover intention. The study contributes to the literature by examining these effect in public sector domain. The study suggests that decision makers must deploy recent leadership styles and establish a trusting relationship among personnel and their superiors. Findings of this study is limited to police personnel. Further generalization of the results require a replicate of this study. More studies are recommended in other public sectors in developing countries.

\section{REFERENCES}

1. Kim, L. Tam, J. N. Kim, and Y. Rhee, "Determinants of employee turnover intention: Understanding the roles of organizational justice, supervisory justice, authoritarian organizational culture and organization-employee relationship quality. 308-328.," Corp. Commun. An Int. J., vol. 22, no. 3, pp. 308-328, 2017.

2. M. Alhashmi, F. Jabeen, A. D. Al-Nasser, and A. Papastathopoulos, "The antecedents of employee turnover intentions in the police force in the United Arab Emirates: A conceptual framework," Int. J. Bus. Soc., vol. 18, no. S3, pp. 449-462, 2017.

3. H. J. (Annette) Kang, J. Busser, and H.-M. Choi, "Service climate: how does it affect turnover intention?," Int. J. Contemp. Hosp. Manag., vol. 30, no. 1, pp. 76-94, 2018.
4. Kim, J. Im, and J. Hwang, "The effects of mentoring on role stress, job attitude, and turnover intention in the hotel industry," Int. J. Hosp. Manag., vol. 48, pp. 68-82, 2015.

5. R. W. Griffeth and P. W. Hom, "A comparison of different conceptualizations of perceived alternatives in turnover research," $\mathrm{J}$ Organ. Behav., vol. 9, no. 2, pp. 103-111, 1988.

6. S. Alaarj, Z. A. Mohamed, and U. S. A. Bustamam, "Do Knowledge Management Capabilities Reduce the Negative effect of Environment Uncertainties on Organizational Performance? A Study of Public Listed Companies in Malaysia," Int. J. Econ. Res., vol. 14, no. 15, pp. 443-456, 2017.

7. W. Rahman and Z. Nas, "Employee development and turnover intention: theory validation," Eur. J. Train. Dev., vol. 37, no. 6, pp. 564-579, 2013.

8. C. Khalife, "Revolving Doors: An Analysis Of The UAE's High Staff Turnover Rate," Entrepreneur, no. 2, Abu Dhabi, pp. 223-233, 01May-2016.

9. S. Biswas, "Relationship between psychological climate and turnover intentions and its impact on organisational effectiveness: A study in Indian organisations,” IIMB Manag. Rev., vol. 22, no. 3, pp. 102-110, 2010 .

10. M. Ohana and M. Meyer, "Should I stay or should I go now? Investigating the intention to quit of the permanent staff in social enterprises," Eur. Manag. J., vol. 28, no. 6, pp. 441-454, 2010.

11. J. Te Yang, "Antecedents and consequences of job satisfaction in the hotel industry,” Int. J. Hosp. Manag., vol. 29, no. 4, pp. 609-619, 2010.

12. H. A. Dardar, A. Jusoh, and A. Rasli, "The Impact of Job Training, job satisfaction and Alternative Job Opportunities on Job Turnover in Libyan Oil Companies," Procedia - Soc. Behav. Sci., vol. 40, pp. 389 394, 2012.

13. D. Kara, M. Uysal, M. J. Sirgy, and G. Lee, "The effects of leadership style on employee well-being in hospitality," Int. J. Hosp. Manag., vol. 34, no. 1, pp. 9-18, 2013.

14. D. A. Yousef, "Organizational Commitment, Job Satisfaction and Attitudes toward Organizational Change: A Study in the Local Government," Int. J. Public Adm., vol. 40, no. 1, pp. 77-88, 2017.

15. Park and H. G. Rainey, "Leadership and public service motivation in U.S. federal agencies,” Int. Public Manag. J., vol. 11, no. 1, pp. 109 142, 2008.

16. A. Puni, C. B. Agyemang, and E. S. Asamoah, "Leadership Styles, Employee Turnover Intentions and Counterproductive Work Behaviours,” Int. J. Innov. Res. Dev., vol. 5, no. 1, pp. 1-7, 2016.

17. [17] S. Bhargavi and I. Shehhi, "Leadership Styles and Organizational Performance," Strateg. Manag. Q., vol. 4, no. 1, pp. $87-$ 117, 2016.

18. G. A. Sulamuthu and H. M. Yuso, "Leadership Style and Employee Turnover Intention," in Proceedings of the International Conference on Industrial Engineering and Operations Management, 2018, no. 2001, pp. 2298-2306.

19. L. Wang, R. Law, K. Hung, and B. D. Guillet, "Consumer trust in tourism and hospitality: A review of the literature," J. Hosp. Tour. Manag., vol. 21, pp. 1-9, 2014.

20. S. Alaarj, Z. Abidin-Mohamed, and U. S. B. A. Bustamam, "Mediating Role of Trust on the Effects of Knowledge Management Capabilities on Organizational Performance," Procedia - Soc. Behav. Sci., vol. 235, pp. 729-738, Nov. 2016.

21. R. Zeffane and B. S. J. Melhem, "Trust, job satisfaction, perceived organizational performance and turnover intention: a public-private sector comparison in the United Arab Emirates," Empl. relations Int. J., vol. 39, no. 7, pp. 1148-1167, 2017.

22. S. Alaarj, Z. A. Mohamed, and U. S. A. Bustamam, "The Effect of Knowledge Management Capabilities on Performance of Companies : A Study of Service Sector,” Int. J. Econ. Res., vol. 14, no. 15, pp. $457-$ 470, 2017.

23. S. Alaarj, A. M. Zainal, and U. Bustamam, "The Effect of Knowledge Management Capabilities on the Performance of Malaysian LargeScale Organizations: An Empirical Study," Adv. Glob. Bus. Res., vol. 12, no. 1, pp. 1024-1038, 2015.

24. J. Al-Kuttab, "How tireless Abu Dhabi Police keeps city safe," Khaleej Times, Abu Dhabi, 24-Jul-2017.

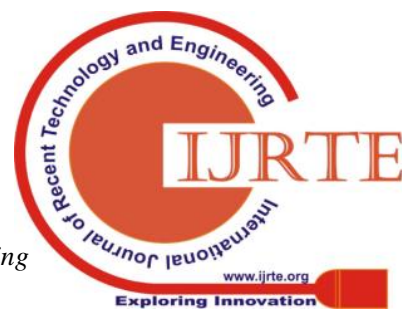


25. C. Maceda, "Staff retention is biggest challenge for companies in UAE: study," Gulf News, Abu Dhabi, 23-Aug-2017.

26. S. Amdan, R. A. Rahman, S. A. M. Shahid, S. A. Bakar, M. M. Khir, and N. A. R. Demong, "The Role of Extrinsic Motivation on the Relationship between Office Environment and Organisational Commitment," Procedia Econ. Financ., vol. 37, no. 16, pp. 164-169, 2016

27. .Alaaraj, Z. A. Mohamed, and U. S. Ahmad Bustamam, "External Growth Strategies and Organizational Performance in Emerging Markets: The Mediating Role of Inter-Organizational Trust," Rev. Int. Bus. Strateg., vol. 28, no. 2, pp. 206-222, 2018.

28. M. L. Zorn, P. M. Norman, F. C. Butler, and M. S. Bhussar, "Cure or curse: Does downsizing increase the likelihood of bankruptcy?," J. Bus. Res., vol. 76, pp. 24-33, 2017.

29. E. A. Brown, N. J. Thomas, and R. H. Bosselman, "Are they leaving or staying: A qualitative analysis of turnover issues for Generation Y hospitality employees with a hospitality education," Int. J. Hosp. Manag., vol. 46, pp. 130-137, 2015.

30. A.S. Harhara, S. K. Singh, and M. Hussain, "Correlates of employee turnover intentions in oil and gas industry in the UAE," Int. J. Organ. Anal., vol. 23, no. 3, pp. 493-504, 2015.

31. Machado Dias Ramalho Luz, S. Luiz de Paula, and L. Maria Barbosa de Oliveira, "Organizational commitment, job satisfaction and their possible influences on intent to turnover," Rev. Gestão, vol. 25, no. 1, pp. 84-101, 2018.

32. M. Nair, "Staff turnover in the UAE higher than global average: report," Gulf News, Abu Dhabi, 17-Oct-2017.

33. H. M. Abu Elanain, "Testing the direct and indirect relationship between organizational justice and work outcomes in a non-Western context of the UAE," J. Manag. Dev., vol. 29, no. 1, pp. 5-27, 2010.

34. A. M. Suliman and H. Al Obaidli, "Organizational climate and turnover in Islamic banking in the UAE," Int. J. Islam. Middle East. Financ. Manag., vol. 4, no. 4, pp. 308-324, 2011

35. S. Cherian, A. J. Alkhatib, and M. Aggarwal, "Relationship between organizational commitment and job satisfaction of nurses in Dubai hospital,” J. Adv. Soc. Sci. Humanit., vol. 4, no. 1, pp. 36373-36400, 2018.

36. M. Behery, S. Abdallah, M. Parakandi, and S. Kukunuru, "Psychological contracts and intention to leave with mediation effect of organizational commitment and employee satisfaction at times of recession,” Rev. Int. Bus. Strateg., vol. 26, no. 2, pp. 184-203, 2016.

37. J. M. Burns, "Leadership," in Leadership, 1978, pp. 66-75.

38. A. Zdaniuk and D. R. Bobocel, "The role of idealized influence leadership in promoting workplace forgiveness," Leadersh. Q., vol. 26, no. 5, pp. 863-877, 2015.

39. Bass, "Leadership and performance beyond expectation," New York, NY Free Press, 1985.

40. P. G. Northouse, "Leadership: theory and practice," in Leadership theory and practice, vol. 24, 2012, p. 5.

41. A. H. Eagly, M. C. Johannesen-Schmidt, and M. L. Van Engen, "Transformational, Transactional, and Laissez-Faire Leadership Styles: A Meta-Analysis Comparing Women and Men," Psychological Bulletin, vol. 129, no. 4. pp. 569-591, 2003.

42. A. W. Head and J. Alford, "Wicked Problems: Implications for Public Policy and Management," Adm. Soc., vol. 47, no. 6, pp. 711-739, 2015 .

43. A. Mathieu and P. Babiak, "Tell me who you are, I'll tell you how you lead: Beyond the Full-Range leadership model, the role of corporate psychopathy on employee attitudes," Pers. Individ. Dif., vol. 87, pp. 8 $12,2015$.

44. M. A. Gyensare, L. E. Kumedzro, A. Sanda, and N. Boso., "Linking transformational leadership to turnover intention in the public sector: The influences of engagement, affective commitment and psychological climate," African J. Econ. Manag. Stud., vol. 8, no. 3, pp. 314-337, 2017.

45. H. H. M. Tse, X. Huang, and W. Lam, "Why does transformational leadership matter for employee turnover? A multi-foci social exchange perspective," Leadersh. Q., vol. 24, no. 5, pp. 763-776, 2013.

46. M. A. Gyensare, O. Anku-Tsede, M.-A. Sanda, and C. A. Okpoti, "Transformational leadership and employee turnover intention: The mediating role of affective commitment," World J. Entrep. Manag. Sustain. Dev., vol. 12, no. 3, pp. 243-266, 2016.

47. R. Van Wijk et al., "Social Exchange Theory," Int. J. Hum. Resour. Manag., 2014.
48. J. Dyer and W. Chu, "The determinants of trust in supplier-automaker relations in the US, Japan, and Korea: A retrospective," J. Int. Bus. Stud., 2011.

49. H. Adobor, "Optimal trust? Uncertainty as a determinant and limit to trust in inter-firm alliances," Leadersh. Organ. Dev. J., vol. 27, no. 7, pp. 537-553, 2006.

50. H. A. Tlaiss and A. M. Elamin, "Exploring organizational trust and organizational justice among junior and middle managers in Saudi Arabia: Trust in immediate supervisor as a mediator," J. Manag. Dev., vol. 34, no. 9, pp. 1042-1060, 2015.

51. C. Cheng, T. Bartram, L. Karimi, and S. Leggat, "Transformational leadership and social identity as predictors of team climate, perceived quality of care, burnout and turnover intention among nurses," Pers. Rev., vol. 45, no. 6, pp. 1200-1216, 2016.

52. P. Shockley-Zalabak, K. Ellis, and G. Winograd, "Organizational trust: What it means, why it matters," Organ. Dev. J., vol. 18, no. 4, pp. 35 48, 2000.

53. S. van den Heuvel, R. S. Charissa Freese, and M. van Assen., "How change information influences attitudes toward change and turnover intention: the role of engagement, psychological contract fulfillment, and trust," Leadersh. Organ. Dev. J., vol. 38, no. 3, pp. 398-418, 2017.

54. A. Erturk, L. Vurgun, A. Ert??rk, and L. Vurgun, "Retention of IT professionals: Examining the influence of empowerment, social exchange, and trust," J. Bus. Res., vol. 68, no. 1, pp. 34-46, 2015.

55. R. V Krejcie and D. W. Morgan, "Determining Sample Size For Research Activities, Educational And Psychological Measurement,' Educ. Psychol. Meas., no. 30, pp. 607-610, 1970.

56. A. Tajasom and Z. Ariffin, "Principals' leadership style and school climate: teachers' perspectives from Malaysia," Int. J. Leadersh. Public Serv., vol. 7, no. 4, pp. 314-333, 2013.

57. R. C. Nyhan and H. A. Marlowe, "Development and psychometric properties of the organizational trust inventory.," Eval. Rev., vol. 21, no. 5, pp. 614-635, 1997.

58. P. B. Lowry and J. Gaskin, "Partial least squares (PLS) structura equation modeling (SEM) for building and testing behavioral causa theory: When to choose it and how to use it," IEEE Trans. Prof. Commun., vol. 57, no. 2, pp. 123-146, 2014.

59. Hair, T. M. Hult, C. M. Ringle, and M. Sarstedt, A primer on partial least squares structural equation modeling, 2nd ed. Thousand Oakes, 2017. 